\title{
Macroprudential Policy Versus Other Economic Policies
}

\section{Eva Lorenčič}

Faculty of Economics and Business, University of Maribor, Maribor, Slovenia and Credit Suisse Group AG, Zurich, Switzerland

eva.lorencic@credit-suisse.com

\section{Mejra Festić}

Faculty of Economics and Business, University of Maribor, Maribor, Slovenia

mejra.festic@um.si
CroEconsur

Vol. 23

No. 2

December 2021

pp. 33-66

Received: March 29, 2021

Accepted: May 17, 2021

Review Article

doi:10.15179/ces.23.2.2

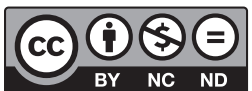

\section{Abstract}

After the global financial crisis of 2007, macroprudential policy instruments have gained in recognition as a crucial tool for enhancing financial stability. Monetary policy, fiscal policy, and microprudential policy operate with a different toolkit and focus on achieving goals other than the stability of the financial system as a whole. In light of this, a fourth policy - namely macroprudential policy - is required to mitigate and prevent shocks that could destabilize the financial system as a whole and compromise financial stability. The aim of this paper is to contrast macroprudential policy with other economic policies and explain why other economic policies are unable to attain financial stability, which in turn justifies the need for a separate macroprudential policy, the ultimate goal whereof is precisely financial stability of the financial system as a whole. Our research results 
based on the descriptive research method indicate that, in order to prevent future financial crises, it is indispensable to combine both the microprudential and the macroprudential approach to financial stability. This is because the causes of the crises are often such that they cannot be prevented or mitigated by relying only on microprudential or only on macroprudential policy instruments.

Keywords: macroprudential policy, monetary policy, microprudential policy, financial stability

JEL classification: E58, G28

\section{Introduction ${ }^{1}$}

After the global financial crisis of 2007, macroprudential policy instruments have gained in recognition as a crucial tool for enhancing financial stability. Monetary policy, fiscal policy, and microprudential policy operate with a different toolkit and focus on achieving goals other than the stability of the financial system as a whole. In light of this, a fourth policy - namely macroprudential policy - is required to mitigate and prevent shocks that could destabilize the financial system as a whole and compromise financial stability.

The first time the term "macroprudential" was used in an official report was in 1986 when the Cross Report was published (BIS, 1986; Bini Smaghi, 2009; Maes, 2010). In the Cross Report, the goal of macroprudential policy was defined as "the safety and soundness of the broad financial system and payments mechanism". The seminal papers by BIS economists which defined the concept of macroprudential policy are Borio (2003), Borio and White (2004), and White (2006). That said, while macroprudential tools may not have been actively used since the early 1990s, they were frequently used and were an integral part of the policy toolkit of the Federal Reserve (Fed) and of the other authorities in the

1 Disclaimer: The views and opinions expressed in this paper are solely those of the authors and do not in any way reflect the official policy, position, or opinion of the Faculty of Economics and Business, University of Maribor or of Credit Suisse Group AG. 
United States between the First World War and the early 1990s (Elliott, Feldberg, \& Lehnert, 2013). They were only not named "macroprudential". Examples of such macroprudential tools used in the US are underwriting standards, stock margin requirements, selective credit controls on portfolios, reserve requirements, interest rate ceilings, capital requirements, supervisory guidance and "direct pressure”, etc. (Elliott et al., 2013). Nowadays macroprudential policy is defined as "the use of primarily prudential tools to limit systemic risk - the risk of disruptions to the provision of financial services that is caused by an impairment of all or parts of the financial system, and can cause serious negative consequences for the real economy" (IMF, 2013b).

The purpose of this paper is to contrast macroprudential policy with other economic policies and explain why other economic policies are unable to attain financial stability, which in turn justifies the need for a separate macroprudential policy, the ultimate goal whereof is precisely financial stability.

We use a qualitative research method of descriptive research. The term "qualitative research" comprises various research traditions and strategies which share certain characteristics: emphasis is placed on how things happen, on the process, on thoughts, beliefs, and attitudes, i.e. on people's experiences, their interpretation of the world around them, and the way they sense and process phenomena (Koh $\&$ Owen, 2000). Inductive reasoning, i.e. the development of hypotheses from observations, is in the foreground. The key research instrument is the researcher and her insights (Koh \& Owen, 2000). Descriptive research as a subfield of qualitative research is based on observation, analysis, and description and is widely used in behavioral sciences, education, epidemiology, and nutrition. Forms of descriptive research are, for instance, observational research and correlational studies (Koh \& Owen, 2000).

The structure of the paper is as follows. In Chapter 2 we outline and contrast various economic policies and their set of objectives, tools, and instruments. In particular, in Chapter 2.1 we compare macroprudential policy with 
microprudential policy; in Chapter 2.2 we explain the similarities and differences between macroprudential and monetary policy; and in Chapter 2.3 we investigate how macroprudential policy interacts with fiscal policy and with structural policies. The final chapter concludes with a summary of our research findings and proposals for future research.

\section{Macroprudential Policy Versus Other Economic Policies}

The overarching goal of macroprudential policy is to promote the stability of the financial system at large. This encompasses the mitigation of the build-up of financial imbalances in expansionary phases of the business cycle, and the bolstering of the resilience of the financial system. In doing so, macroprudential policy safeguards the contribution of the financial sector to economic growth (Schoenmaker, Gross, Langfield, \& Pagano, 2014). Monetary policy also seeks to facilitate non-inflationary and stable economic growth. Microprudential regulatory and supervisory framework aims to safeguard the soundness of individual financial institutions. In doing so, it protects insurance companies' policyholders and banks' depositors. In sum, macroprudential and monetary policy are concerned with the whole economy, whereas microprudential policy targets individual financial institutions. Tinbergen (1952) argued that each policy goal needs to be coupled with at least one independent policy instrument.

Table 1 contrasts the objectives, tools, and instruments of macroprudential policy with the objectives, tools, and instruments of other economic policies. The credit cycle and some other financial cycles can be very powerful. Hence, a joint use of macroprudential, monetary, and fiscal policies may be necessary to tame financial booms and busts (Borio, 2014). 
Table 1: Economic Policies and Their Set of Objectives, Tools, and Instruments

\begin{tabular}{|c|c|c|}
\hline & Objective & Examples of tools and instruments \\
\hline Microprudential policy & $\begin{array}{l}\text { Limit distress at the level of } \\
\text { individual institutions }\end{array}$ & $\begin{array}{l}\text { Leverage ratio, capital ratio, liquidity } \\
\text { ratios }\end{array}$ \\
\hline Macroprudential policy & Limit financial system distress & LTV, DTI, stress test, leverage ratios \\
\hline Monetary policy & $\begin{array}{l}\text { Price stability } \\
\text { Liquidity management } \\
\text { Lean against financial } \\
\text { imbalances }\end{array}$ & $\begin{array}{l}\text { Key policy rate, standard repurchase } \\
\text { agreements (repos) } \\
\text { Policy corridors, interest rate on reserves } \\
\text { Key policy rate, reserve requirements, } \\
\text { FX reserve buffers }\end{array}$ \\
\hline Fiscal policy & $\begin{array}{l}\text { Manage aggregate demand } \\
\text { Build fiscal buffers in good } \\
\text { times }\end{array}$ & $\begin{array}{l}\text { Taxes, discretionary countercyclical } \\
\text { measures } \\
\text { Measures to reduce debt levels }\end{array}$ \\
\hline Capital controls & $\begin{array}{l}\text { Limit system-wide currency } \\
\text { mismatches }\end{array}$ & $\begin{array}{l}\text { Limit open foreign exchange positions } \\
\text { on the type of foreign currency assets }\end{array}$ \\
\hline Infrastructure policies & $\begin{array}{l}\text { Strengthen the resilience of the } \\
\text { infrastructure of the financial } \\
\text { system }\end{array}$ & $\begin{array}{l}\text { Move derivative trading to regulated } \\
\text { exchanges }\end{array}$ \\
\hline
\end{tabular}

Sources: Galati and Moessner (2011) and Tomuleasa (2015).

Mundell (1962) applied this principle to the goals of internal and external stability. He advised that fiscal policy be assigned to the achievement of internal stability, defined as full employment, and monetary policy be assigned to the attainment of external stability, defined as exchange rate stability (Mundell, 1962). However, both policies, instruments, and goals are intrinsically intertwined, just like macroprudential, monetary, and microprudential policy are interrelated (Schoenmaker et al., 2014). Figure 1 depicts the policy framework for the financial and economic system. Each policy has a direct impact on its first goal and an indirect (or direct, but less pronounced) effect on other goals which are primarily entrusted to another policy. The solid line in Figure 1 represents the primary impact, whereas the dotted lines illustrate secondary impacts. For instance, a change in the interest rate in the first instance impacts output and price stability; however, it can also cause changes in asset prices (hence impacting financial stability) and changes in the creditworthiness of borrowers and values of securities held by banks and insurance companies (hence impacting the soundness and stability of financial institutions) (Schoenmaker et al., 2014). 
Figure 1: Policy Framework for the Financial and Economic System

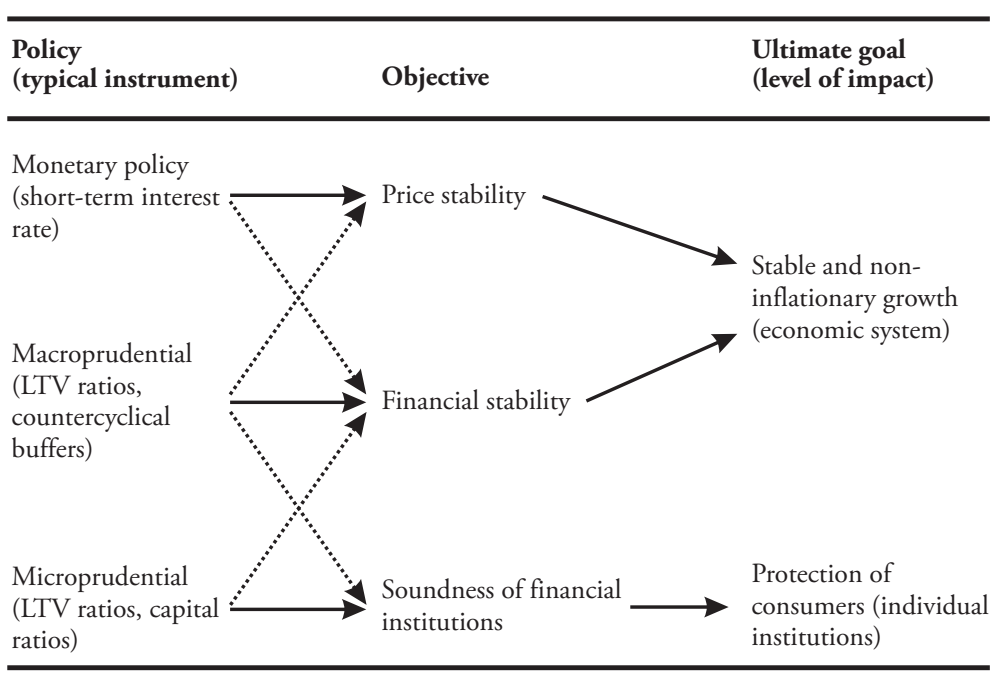

Source: Schoenmaker et al. (2014)

\subsection{Macroprudential Policy Versus Microprudential Policy}

Until recently, the widely accepted approach to financial stability posited that if individual institutions are safe, the financial system as a whole will also be safe. This idea, which was the underlying premise of the original Basel Accord, after the last global financial crisis of 2007 turned out to be a fallacy. Namely, when trying to make themselves more stable, sound, and resilient, financial institutions can behave in a way which unravels the stability of the system (Schoenmaker et al., 2014). For instance, selling an asset may be prudent from the perspective of an individual institution; however, if many or all institutions simultaneously sell a particular asset, the price of this asset will collapse, which may in turn threaten the stability of the system (this may happen if one sale triggers other sales, which leads to a wide-ranging decline in asset prices, tighter correlations, and volatility). A microprudential approach can thus be calamitous at the macroprudential level (Schoenmaker et al., 2014). There can be tensions between 
microprudential and macroprudential authorities. From a microprudential point of view, it may be sensible to increase capital requirements of individual banks during financial distress to bolster their resilience. On the other hand, such capital increases may be procyclical from a macroprudential perspective and can lead to a worsening of financial stress. Such tensions between the macroprudential and microprudential perspective can slow down decision-making, prevent timely intervention, and generate policy confusion (IMF, 2011; Osinski, Seal, \& Hoogduin, 2013; Bengtsson, in press). Table 2 lays down the differences between the macroprudential and microprudential perspective.

The banks' funding sources are predominantly deposits insured by an explicit or implicit government guarantee. Such deposit insurance prevents runs on the banks (Bryant, 1980; Diamond \& Dybvig, 1983); however, it simultaneously incentivizes bank managers to take excessive risks, since they know that potential losses will be covered by the taxpayers. Capital regulation requires the banks to internalize losses (by using up their own capital), which reduces the probability that the deposit insurer will have to bear losses, and hence alleviates the moral hazard problem (Hanson, Kashyap, \& Stein, 2011). A microprudential regulator is focused on the capital ratio of individual banks, implying that the regulator is indifferent about how a sufficiently high capital ratio is achieved, maintained, and restored - via the numerator (by raising new capital) or the denominator (by reducing assets - for instance, by reducing lending). Such indifference is not harmful in normal times when other banks can absorb the assets discarded by the bank in question (Hanson et al., 2011). That said, if the financial system is in dire straits and if many banks attempt to reduce their assets, the economy will suffer. The macroprudential approach to financial regulation attempts to mitigate the social costs (credit crunch and fire sale effects) ensuing from excessive balancesheet shrinkage of several financial institutions which are hit by a common economic shock (Hanson et al., 2011). In general, the banks are incentivized to reduce their assets rather than to acquire additional capital once they find themselves in a crisis, and to function with insufficient capital buffers prior to the 
occurrence of a crisis, which increases the likelihood of a crisis and a contraction in the balance sheets of many banks. The macroprudential approach to financial regulation intends to offset these two banks' propensities (Hanson et al., 2011).

What differentiates the macroprudential approach from the microprudential one? While the microprudential approach focuses on the stability, resilience, and soundness of individual financial institutions, the macroprudential approach focuses on the financial system as a whole. Moreover, the microprudential approach treats risk as given - that is, exogenous (individual institutions have no influence on the global risk outlook), whereas the macroprudential approach treats risk as endogenous - dependent on the collective behavior of financial institutions (Crockett, 2000; Lamfalussy, 2004; Borio, 2009). Furthermore, microprudential policy is concerned with limiting the likelihood of failure of individual institutions (idiosyncratic risk), whereas macroprudential policy focuses on systemic risk and amplification mechanisms which arise through correlations and common exposures to macroeconomic risk factors. The macroeconomic approach advocates a top-down approach to regulation and supervision, where an institution's systemic importance is a key factor in calibrating regulatory requirements and supervisory treatment. The macroprudential approach to financial stability prescribes the build-up of buffers in expansionary periods, when risks and financial imbalances are growing (Maes, 2010). Sometimes there are conflicts between microprudential and macroprudential objectives - for instance, in a downturn a microprudential authority would tend to raise the required capital and liquidity ratios so as to protect the creditors of individual financial institutions. On the other hand, a macroprudential authority would aim to prevent the banks from destabilizing the system as a whole through credit contractions and asset fire sales - even perhaps at the cost of letting individual institutions go under. In order to fulfill this goal, a macroprudential authority would tend to lower the required capital and liquidity ratios (Giese, Nelson, Tanaka, \& Tarashev, 2013). 
Table 2: Macroprudential Perspective Versus Microprudential Perspective

\begin{tabular}{|c|c|c|}
\hline & Macroprudential & Microprudential \\
\hline Immediate objective & $\begin{array}{l}\text { To limit instability at system } \\
\text { level }\end{array}$ & $\begin{array}{l}\text { To limit problems at } \\
\text { institutions' level }\end{array}$ \\
\hline Ultimate objective & $\begin{array}{l}\text { To avoid macroeconomic } \\
\text { costs associated with financial } \\
\text { instability }\end{array}$ & $\begin{array}{l}\text { Consumer protection (investor/ } \\
\text { depositor) }\end{array}$ \\
\hline Risk characterization & $\begin{array}{l}\text { Endogenous (dependent on } \\
\text { collective behavior) }\end{array}$ & $\begin{array}{l}\text { Exogenous (independent from } \\
\text { the behavior of individual } \\
\text { agents) }\end{array}$ \\
\hline $\begin{array}{l}\text { Correlation and common } \\
\text { exposures across institutions }\end{array}$ & Important & Irrelevant \\
\hline Calibration of potential filters & Target risks at system level & Target risks at institutions' level \\
\hline
\end{tabular}

Source: Borio (2003).

There is a tension between the micro- and macroprudential perspective regarding the risk measurement and the behavioral response to it (Crockett, 2000).

In regard to measurement, markets and economic agents seem relatively good at estimating the relative risk of counterparties, debtors, and instruments (Crockett, 2000). Having said that, the assessment of the absolute risk which cannot be diversified is more intricate and necessitates a thorough understanding of correlations among assets and economic agents and their trajectory through time (Crockett, 2000). The collective behavior of institutions influences financial risk and financial distress. An explanation for the forces which propel the economy forward and for the interaction between the real and financial sector would need to incorporate the collective behavior of institutions (Crockett, 2000). Many of the approaches for measuring credit and market risk are based on short-term extrapolation or on time-invariant historical averages. For instance, the valueat-risk (VaR) used for calculating market risk uses mechanical inputs. Many measures of credit risk are likewise mechanical and do not account for the collective behavior of institutions (Crockett, 2000).

In regard to the behavioral response, the incentives in financial markets can exacerbate the problems stemming from difficulties in measuring risk. Shareholders 
can seek excessively high returns if their investment horizon is short (Crockett, 2000). Such competitive pressure can stimulate risk-taking behavior. The usual characteristics of remuneration for traders and contracts for managers likewise encourage excessive risk-taking and the search for high yield (Crockett, 2000). Herd instinct (the inclination to conform to what is perceived as the normal, most widely accepted behavior, or to conform to the group of individuals who are presumably better informed, in the hope of limiting blame in the event of a failure, and for fear of being left behind) adds to this pattern (Crockett, 2000). The perceptions of official "safety nets" can likewise lead financial institutions to take on excessive risks.

All of these behavioral patterns may appear reasonable when observed in isolation; however, when the system-wide impact of collective behavior is considered, the outcomes may be undesirable and can result in large economic and social costs (Crockett, 2000). This is why macroprudential regulation which takes into account the systemic perspectives is indispensable.

\subsection{Macroprudential Policy Versus Monetary Policy}

Price stability and financial stability are complementary and can reinforce each other. The financial stability objective mitigates excessive credit granting and credit growth, constrains unsustainable increase in asset prices, and dampens the procyclical reinforcing relationship between financial and real variables, thereby supporting price stability $(\mathrm{ECB}, 2013)$. The price stability objective constrains distortions in the financial market which could be caused by unchecked inflation, anchors inflation expectations and hence limits the unravelling of shocks, and curbs procyclicality in the economy, thereby promoting financial stability (ECB, 2013). Price stability is a prerequisite for financial stability, but it is not a sufficient condition for it. Indeed, the period just before the last global financial crisis of 2007 took place was characterized by price stability, low macroeconomic volatility, and 
favorable risk perception. In spite of these seemingly stable conditions, financial imbalances grew to unprecedented levels and, in 2007, unraveled (ECB, 2013).

Monetary policymakers believed for a long period of time that monetary policy should not attempt to correct financial imbalances and asset price distortions. This view, however, has changed in the aftermath of the 2007 global financial crisis (ECB, 2013). Now the predominant view is that either a separate macroprudential policy should respond to misalignments in the financial cycle or monetary policy should counteract asset price misalignments caused by overly optimistic, excessive credit growth and substantial capital flows which can suddenly reverse and devastate the economy (ECB, 2013). Many policymakers are reluctant to employ monetary policy for anything other than targeting core macroeconomic objectives, i.e. output and inflation (Akinci \& Olmstead-Rumsey, 2018). In general, many policymakers prefer to use cyclical macroprudential policy instruments as the first line of defense against financial stability risk, and monetary policy only as the last line of defense (Akinci \& Olmstead-Rumsey, 2018).

The global financial crisis of 2007 led to a rediscovery of the notion of financial cycles, as first described by Minsky (1977) and Kindleberger (1978). The notion of financial cycles refers to endogenous cycles stemming from the changing perception of financial risk (Fahr \& Fell, 2017). Financial cycles start with financial exuberance which sets off financial imbalances and ultimately leads to a "Minsky moment", at which point the asset values suddenly and strongly decline and a financial crisis erupts (Fahr \& Fell, 2017). The financial cycles need to be tamed (Barwell, 2013). Since financial cycles fluctuate more heavily and are longer in duration than business cycles, the financial and the business cycles are desynchronized (Borio \& Drehmann, 2009; Schüler, Hiebert, \& Peltonen, 2015; Claessens, Kose, \& Terrones, 2011; Claessens, Ghosh, \& Mihet, 2013). Given that monetary policy targets the business cycle, its instruments are not appropriate for a simultaneous targeting of the financial cycle. Moreover, the interest rates are a blunt tool which causes changes in the entire economy, implying that this instrument cannot be used if only a particular set of financial imbalances or asset 
prices needs to be corrected. This is where a separate macroprudential policy comes into play.

Figure 2: Divergent Stylized Financial and Business Cycles



Notes: The financial cycle in the picture has a length of 8 years (96 months) and an amplitude of 2 . The business cycle has a length of 4 years ( 48 months) and an amplitude of 1 .

Source: Fahr and Fell (2017).

Figure 2 depicts a stylized example where the financial cycle has double the amplitude and the duration of the business cycle. The region between points $\mathrm{B}$ and $\mathrm{C}$ illustrates circumstances where the output is below its potential (business cycle is in a downswing), whereas the financial cycle is expanding, implying that financial imbalances are growing (Fahr \& Fell, 2017). If the only available policy instrument in such a situation is the interest rate, there will be a conflict of goals. Namely, raising the interest rate to contain the build-up of financial imbalances could simultaneously lead to a decline in inflation below the target price level (Fahr \& Fell, 2017). Conversely, the region between points C and D represents 
a situation where the business cycle is expanding, whilst the financial cycle is contracting. A decline in interest rates would likely lead to rising prices in the economy, hence compromising the price stability objective (Fahr \& Fell, 2017). However, this would encourage the financial cycle to pick up, thus achieving the financial stability objective. The price stability objective and the financial stability objective will be aligned only close to points $\mathrm{A}$ and $\mathrm{E}$, which is only about one quarter of the time (Fahr \& Fell, 2017).

According to the Tinbergen principle (Tinbergen, 1952), one policy instrument cannot be used to target more than one policy objective. Given that price stability and financial stability are two different objectives, two different policies and (at least) two different policy instruments are required to achieve them (Fahr \& Fell, 2017). The macroprudential policy toolkit which has started to take shape after 2007 is granular and broad, implying that it is well-suited to mitigate financial vulnerabilities and risks at the level of systemically important financial institutions, specific sectors of the economy, or countries. Some of these tools (e.g. capital controls, reserve requirements, and credit limits) have existed for quite some time, but now they are incorporated into a clearly-defined macroprudential policy framework (Fahr \& Fell, 2017). Mundell (1962) demonstrated that policy instruments should be coupled with those goals on which they can exert the most influence. Since macroprudential policy is more appropriate for targeting the financial stability objective and monetary policy is more suitable for targeting the price stability objective, monetary policy does not have to "lean against the wind" (i.e. attempt to address financial imbalances as they build up), since this goal is already being accomplished by macroprudential policy (Fahr \& Fell, 2017). This reduces the risk of monetary policymakers compromising the pursuit of the price stability objective because they are distracted by financial stability considerations (Fahr \& Fell, 2017).

The monetary policy strategy of the European Central Bank (ECB) indirectly includes asset price dynamics into policy conduct by drawing on the linkage between monetary and credit developments and asset price dynamics (ECB, 
2013). It constrains the possibility of asset prices increasing excessively and overly optimistic expectations developing further by monitoring and comparing the developments in the credit market and in the asset markets, as well as by checking the trajectory of liquidity indicators. Such a monetary policy positioning is a prerequisite for crisis prevention, but it is not sufficient (ECB, 2013). Monetary policy can support and complement macroprudential policy by suppressing unreasonable credit growth and leverage, stifling excessive risk-taking incentives, and curbing the propagation of financial risk. The interaction between both policies is impacted by the degree of overlap between financial and real cycles, and hence by the financial and real shocks in the economy, as well as by the similarities and differences between the transmission mechanisms of both policies (ECB, 2013). In the euro area, macroprudential policy can be used to tackle the country-specific developments which the uniform monitory policy cannot address. Moreover, if asset markets and credit markets in the euro area are expanding, but the general price level (which is a measure of inflation and is relevant for monetary policy conduct) stays the same, macroprudential policy comes into play to keep the financial markets in check (ECB, 2013).

The uniform monetary policy is not capable of shielding a particular country when it is hit by an asymmetric shock or when the reaction of a certain country to a common disturbance is different because of structural peculiarities of that country (Rubio \& Comunale, 2018). The heterogeneity of the euro area member states is manifested by, for example, the type of rates (fixed versus variable) at which housing loans are granted. In Spain the percentage of loans extended at fixed rates is 82 percent, in Lithuania around 80 percent, whereas in France and Germany it is only 12 percent and 15 percent, respectively (Rubio \& Comunale, 2018). Hence, there are considerable differences in the mortgage markets among different euro area member states. Countries of a currency union have limited possibilities to adjust their domestic macroeconomic circumstances. The build-up of systemic risk and the characteristics of financial cycles are frequently country-specific; however, spillovers to the other economies can happen (Rubio \& Comunale, 
2018). Since there is no country-specific monetary policy in the euro area, a macroprudential policy tailored to individual countries is all the more important. Many of the available macroprudential policy instruments can influence output and inflation, implying that macroprudential policy can strengthen the monetary policy stance, but can also oppose it (Rubio \& Comunale, 2018).

Macroprudential policy needs to take into account structural characteristics of the financial system and the credit cycle of a particular country. Low monetary policy interest rates, which may be needed to fulfill the price stability goal, might set off asset price bubbles which could endanger financial stability (Rubio \& Comunale, 2018). This is where macroprudential policy comes into play by employing specific instruments designed to mitigate financial stability risks. A combination of macroprudential and monetary policy can simultaneously achieve financial stability and price stability (Rubio \& Comunale, 2018). In the European Union, the ECB is responsible for the fulfillment of the price stability objective, whereas the national macroprudential authorities and the European Systemic Risk Board (ESRB) are in charge of monitoring financial stability risks and activating macroprudential policy instruments (Rubio \& Comunale, 2018). Hence, macroprudential policy and monetary policy remain separated; however, the ESRB is hosted by the ECB, and the members of the ESRB's General Board are the President and the Vice-President of the ECB and the governors of the national central banks of the EU member states, implying that the same persons are overseeing macroprudential and monetary policy decisions.

Macroprudential policy is needed because monetary policy cannot achieve both price stability and financial stability. While macroprudential policy is geared towards influencing the specific financial conditions for lenders and borrowers, monetary policy shapes the general financial conditions of the economy (Tröger, 2015). Both macroprudential and monetary policy are capable of influencing both price and financial stability objectives. Hence the question of how complementary or offsetting these two policies are and which of the two objectives should be assigned to each of them. Fahr and Fell (2017) empirically investigate 
the relative effectiveness of macroprudential and monetary policy instruments in attaining price and financial stability objectives. Macroprudential policy proves to be more effective than monetary policy at improving financial system resilience and at moderating the financial cycle. On the other hand, monetary policy is more effective than macroprudential policy in attaining price stability. The corollary of these findings is that macroprudential policy should aim at achieving financial stability, whereas monetary policy's objective should be price stability. By extension, monetary policy interest rate should not be employed for achieving financial stability, and macroprudential policy should not be used for attaining price stability (Fahr \& Fell, 2017). Svensson (2018) arrives at similar conclusions: macroprudential and monetary policy are quite different policies with different appropriate goals, instruments, and in many economies different responsible authorities. There is some small overlapping effect of the two policies macroprudential policy has a slight, indirect, and unsystematic effect on inflation and resource utilization (which are otherwise the key objectives of monetary policy), whereas monetary policy has a slight, indirect, and unsystematic impact on financial stability (which is otherwise the primary goal of macroprudential policy). Bearing this in mind, while each policy should be focused on attaining its own objectives, it should also pay due attention to the stance of the other policy (Svensson, 2018).

Monetary policy accommodation can mitigate the impact of the tightening of macroprudential policy (ECB, 2013). Moreover, monetary policy can act as a shield against macroeconomic (mis)allocations caused by a decline in investment and consumption, a fall in house prices and asset prices, a decrease in collateral, and a tightening of borrowing constraints (all of which are caused by macroprudential tightening) (ECB, 2013). By contrast, a simultaneous increase in capital requirements (caused by a tighter macroprudential policy) and interest rates (caused by a tighter monetary policy) will likely cause a decline in bank lending and in economic activity (ECB, 2013). There can be a potential conflict of interest or trade-off between macroprudential and monetary policy 
(ECB, 2013): a too restrictive macroprudential policy can impair the provision of credit in the economy, which has a detrimental impact on the monetary policy transmission mechanism. Similarly, a too loose monetary policy can amplify the financial cycle and its inherent vulnerabilities. Macroprudential policies seem to be more effective when they work in tandem with monetary policy to strengthen monetary tightening as opposed to when they operate in opposite directions (Bruno, Shim, \& Shin, 2017). A combination of monetary and macroprudential policy can achieve financial and monetary stabilization (IMF, 2013a). Hence, there is a need to set up a coordination framework between the two policies, a suitable institutional set-up, and a clear division of responsibilities (Cecchetti \& Kohler, 2012; Ueda \& Valencia, 2012; ECB, 2013).

Table 3 compares the various aspects of monetary policy and macroprudential policy frameworks. Monetary policy determines the risk-free interest rate, which in turn sets the price of debt and leverage. By extension, economic agents adjust their intertemporal consumption decisions, which in turn influences the price levels in the economy (Woodford, 2005; Morris \& Shin, 2008). If the short-term interest rate is lower, whereas long-term interest rate is high, it may make sense for consumers to forego their consumption today, save, and spend more in the future. (However, an individual's consumption versus saving decisions are influenced by many factors - their utility function, temporal myopia, hyperbolic discounting, etc.) Macroprudential policy instruments, on the other hand, target only the financial sector by influencing the price and quantity of risk-taking for banks. They influence the asset-liability mix of the banks' balance sheets and their capital buffers (Tröger, 2015). Loose monetary policy, characterized by low interest rates, might have contributed to the global financial crisis of 2007 because the economic agents were "searching for yield" in potentially riskier exposures and sectors. The monetary policy's risk-taking channel could thus interfere with macroprudential policy goals (Altunbas, Gambacorta, \& Marques-Ibanez, 2014; Adrian \& Shin, 2014; Borio \& Zhu, 2014). Likewise, macroprudential policy can interfere with the monetary policy transmission mechanism. For instance, changes in debt- 
service-to-income and loan-to-value limits could change lending conditions, and, by extension, consumption decisions. Macroprudential policy has an impact on credit conditions, and hence potentially on the real interest rates, which alter the monetary policy stance even if no actual changes in monetary policy by the monetary policy authority were undertaken (Gambacorta \& Murcia, 2020).

Table 3: Comparison of Monetary and Macroprudential Policy Frameworks

\begin{tabular}{|c|c|c|}
\hline & Monetary policy & Macroprudential policy \\
\hline Horizon & - 1-3 years & - longer and more variable \\
\hline Ultimate target & $\begin{array}{l}\text { - price stability, defined as } \\
\text { maintaining low and stable } \\
\text { inflation } \\
\text { reasonable volatility of } \\
\text { economic activity }\end{array}$ & $\begin{array}{l}\text { preventing the formation and spread of } \\
\text { systemic risk (reducing the probability } \\
\text { of occurrence of financial crises with } \\
\text { large output losses and/or costs for public } \\
\text { budgets) } \\
\text { mitigating the impacts of systemic risk if } \\
\text { prevention fails }\end{array}$ \\
\hline $\begin{array}{l}\text { Indicators for } \\
\text { identifying risks } \\
\text { and assessing their } \\
\text { intensity }\end{array}$ & $\begin{array}{l}\text { inflation forecast in relation } \\
\text { to target } \\
\text { output gap, indicators of } \\
\text { capacity utilization and } \\
\text { producers' profit margins, } \\
\text { etc. }\end{array}$ & $\begin{array}{l}\text { - } \text { excessive debt measures } \\
\text { - } \text { risk undervaluation measures } \\
\text { - excess liquidity indicators and property } \\
\text { construction and trading activity } \\
\text { indicators } \\
\text { - indicators of internal and external } \\
\text { balance of the economy } \\
\text { - indicators of the external position of the } \\
\text { financial sector } \\
\text { - investors of leverage among institutions and } \\
\text { - sharket funding ratio and other balance- } \\
\text { asset and liquidity maturity and currency } \\
\text { mismatch indicators }\end{array}$ \\
\hline Intermediate targets & $\begin{array}{l}\text { - money market interest rates } \\
\text { - exchange rate }\end{array}$ & $\begin{array}{l}\text { - resilience and shock-absorbing capacity } \\
\text { of the financial system } \\
\text { - amplitude of the financial cycle } \\
\text { - level of uncertainty regarding the } \\
\text { soundness of the system at times of } \\
\text { financial instability }\end{array}$ \\
\hline Instruments & $\begin{array}{l}\text { - } \text { monetary policy interest rate } \\
\text { interventions } \\
\text { - other reserve requirement } \\
\text { instruments } \\
\text { - communication }\end{array}$ & $\begin{array}{l}\text { built-in stabilizers oriented towards } \\
\text { creating and releasing buffers } \\
\text { macroprudentially applied supervisory } \\
\text { and regulatory instruments } \\
\text { communication }\end{array}$ \\
\hline $\begin{array}{l}\text { Transmission } \\
\text { mechanisms }\end{array}$ & $\begin{array}{l}\text { - bank asset financing costs } \\
\text { - credit costs for bank clients } \\
\text { - foreign trade prices } \\
\text { asset prices }\end{array}$ & $\begin{array}{l}\text { - bank capital and liquidity requirements } \\
\text { banks costs relating to the risk of new } \\
\text { and existing exposures } \\
\text { - penalization of increasing scale of risk } \\
\text { assumed by banks and other financial } \\
\text { institutions }\end{array}$ \\
\hline
\end{tabular}

Source: Frait and Komárková (2011). 
Agénor and Pereira da Silva (2014) construct a dynamic macroeconomic model of a bank-dominated financial system which includes some of the credit market imperfections usually found in middle-income economies. The authors analyze the interactions between macroprudential policy (involving reserve requirements) and monetary policy. Their research methods include a qualitative analysis as well as the calibrated model to numerically investigate the transitional dynamics and steady-state effects of an increase in the reserve requirement ratio with different parameter values. A change in reserve requirements has an impact on many factors (e.g. strength of the cost channel, strength of the wealth and interest rate effect on aggregate demand, response of monetary policy to the level of inflation) which affect excess demand (hence inflationary pressure). In the long run, the impact of a change in the reserve requirement ratio may be contradictory - lower reserve requirements may actually reduce excess demand, thereby reducing the inflation rate. Understanding the operation of macroprudential policy tools is of utmost importance, since they may affect the monetary transmission mechanism, thereby interfering with monetary policy.

Similarly, Tayler and Zilberman (2016) shed light on the roles of macroprudential policy and monetary policy in a model with financial frictions, such as credit risk, bank losses, and bank capital costs. In the presence of credit shocks, macroprudential countercyclical regulation is found to be more effective than monetary policy in achieving price, financial, and macroeconomic stability. In this setting, the unfavorable procyclical spillover consequences of a financial shock are completely eliminated by a countercyclical response to credit risk which restores the equilibrium price of credit. In the face of supply shocks, a combination of macroprudential regulation with monetary (anti-inflationary) policy proves to be most efficient. In this setting, a countercyclical response to credit risk makes it possible for the policymaker to resist supply shocks, but not to eliminate them altogether. The source of economic shocks thus first needs to be identified for the policymakers to be able to make the right decisions about macroprudential and monetary policy response. The results of the study lead us to believe that 
the macroprudential provisions of Basel III standards are needed and effective in moderating the output-inflation trade-off.

In a comparable fashion, Greenwood-Nimmo and Tarassow (2016) investigate the impacts of monetary and macroprudential shocks on financial fragility, measured as credit extension (credit to GDP ratio) and as financial ratio (ratio of corporate credit to internal funds). The findings of the study show that a contractionary monetary shock exacerbates financial fragility by increasing the credit to GDP ratio as well as by increasing the ratio of corporate credit to internal funds. On the other hand, a credit-constraining macroprudential shock in isolation (if interest rates are free to adjust to the macroprudential shock) reduces the credit to GDP ratio in the short run, but does not reduce the financial ratio. However, if macroprudential policy is not used in isolation (if interest rates are free to adjust to the macroprudential shock), both the credit to GDP ratio and the financial ratio significantly decline. In light of these findings, it can be concluded that a combination of monetary and macroprudential policies may be the most suitable for attaining financial stability.

Another similar study is that of Kiley and Sim (2017), who employ a quantitative model to shed light on the interaction of monetary and macroprudential policies. The findings of the empirical analysis are that monetary policy should react strongly to differences in credit spreads, as it can only partially insulate the economy from the negative effects of financial shocks. On the other hand, optimal macroprudential policy (leverage tax according to Ramsey) can increase welfare and stabilize macroeconomic activity in the face of financial shocks to intermediation. Certain financial shocks are better suited to monetary stabilization (notably risk premium and natural rate of interest shocks), whereas some others are more amenable to the macroprudential approach (in particular shocks to intermediation, as captured by volatility shocks). Both types of shocks are relevant for credit spread fluctuations; however, the shocks to intermediation are less relevant for economic fluctuations, implying that the effectiveness of simple macroprudential rules is constrained. 
In a similar vein, Klingelhöfer and Sun (2019) use the case of China to demonstrate that reserve requirements, supervisory pressure, and housingmarket policies can be employed for macroprudential purposes. Their empirical results show that select macroprudential policy measures have a clear-cut effect on credit, but no significant impact on output. Macroprudential policy may be employed to maintain financial stability without a reduction in economic activity, or as a supplement to monetary policy to alleviate the build-up of financial vulnerabilities which are a side effect of expansionary monetary policy. A multiinstrument framework is optimal, since a mix of macroprudential and monetary policy seems to be best placed to attain both financial stability and price stability/ macroeconomic stability objectives.

Similarly, Bruno et al. (2017) investigate the effectiveness of macroprudential policies in twelve Asia-Pacific economies over the time span 2004-2013 by drawing on macroprudential and capital flow management (CFM) data. The findings of the study demonstrate that banking sector and bond market CFM tools have a positive effect on reducing the growth in bank inflows and bond inflows. Another finding of the study is that macroprudential policies (banking inflow measures) are more effective in slowing down cross-border lending when they act in tune with monetary policy, contributing to monetary tightening, than when both policies pull in opposite directions. This is consistent with the fact that when macroprudential and monetary policy work in opposite directions, economic agents receive contradictory signals - they are simultaneously told to borrow more and to borrow less.

Along the same lines, Rubio and Carrasco-Gallego (2014) examine the effects of macroprudential and monetary policy implementation on business cycles, welfare, and financial stability. The empirical results suggest that the stability of the system is enhanced when both macroprudential and monetary policy act in a coordinated way (as opposed to when they act in a non-coordinated manner). In the face of a technology or housing demand shock, the macroprudential authority would reduce the loan-to-value (LTV) cap so as to reign in the credit boom, 
thereby attaining its ultimate goal of financial stability. The interaction between both policies improves welfare for the society (in particular when both policies act in a non-coordinated manner). There is, however, a trade-off in welfare between borrowers and savers in the non-coordinated game. This notwithstanding, the savers' welfare loss can be offset by the borrowers to attain a Pareto-superior result.

Similarly, Rubio and Comunale (2018) examine the impact of macroprudential policies in a monetary union on macroeconomic and financial stability in Lithuania and in the rest of the euro area. Two different macroprudential policy frameworks are considered in the model: one where the ECB includes financial stability into its policy goals, and another where a national macroprudential authority uses a certain macroprudential policy instrument (the LTV ratio). Both policy frameworks prove to be effective in increasing the resilience of the financial system. When financial stability is included into the ECB's policy goals, inflation volatility increases. On the other hand, the LTV rule does not lead to higher inflation volatility. As such, having two different instruments for two different policy goals is a better choice from the cost-benefit perspective.

An opposing view is held by van den End (2016), who criticizes the position of the ECB and the Fed that price stability is the primary goal of monetary policy and quantitative easing $(\mathrm{QE})$, whereas financial stability is secondary and addressed by macroprudential policy. Van den End (2016) in his paper argues that financial stability should not be separated from monetary policy as manifested through QE. A regression analysis for a set of eleven countries demonstrates that a decline in equity prices and an increase in corporate bond rates leads to a decrease in the inflation rate. Hence, liquidity-driven booms can have an adverse impact on inflation, which is an argument for taking into consideration asset bubbles when designing monetary policy. Since asset bubbles harm both financial stability and inflation, asset price developments and financial stability concerns should be accounted for in the conduct of QE. 
While most of the research centered around macroprudential policy argues for its usage and necessity, and presents its advantages and complementarities to other policies, at the same time making the case for how other available policies (notably monetary policy) are ill-suited for fulfilling the financial stability objective, Malz (2019) puts forward the argument that macroprudential policy cannot rectify the existing regulatory system which increases risks to financial stability. According to Malz (2019), banks are inadequately capitalized and possibly overly leveraged; moreover, the big banks are too opaque and complex for their risks to be properly analyzed and understood. The safety nets and the possibility of a bailout exacerbate the too-big-to-fail (TBTF) and moral hazard problems. The aforementioned problems should be addressed at the root instead of through additional policies and rules. The rationale for macroprudential policy presumes that policymakers have access to unrealistically detailed and broad knowledge about the financial system, and the ability to correct certain systemic weaknesses in a predictable manner. First banks should be stabilized and better capitalized, while the implicit and explicit public sector guarantees should be abolished; only thereafter, if needed, could specific tools be designed to complement monetary policy (Malz, 2019). The view of Malz (2019) contradicts most of the existing research on macroprudential policy. This notwithstanding, opposing views must be discussed and considered, as they may also have merit.

\subsection{Interaction of Macroprudential Policy With Fiscal Policy and With Structural Policies}

When tax policies give incentives to increase leverage, they can amplify systemic risk. This happens when interest payments are tax deductible or when they influence asset prices (Keen $\&$ de Mooij, 2012). Macroprudential authorities strive to turn around such incentives. Taxes can influence how macroprudential policies are carried out even when they do not directly increase the risk-taking behavior (Claessens, 2014). Real estate taxes, such as property taxes and stamp duties, can have an impact on house prices, implying that tax policies are relevant for 
financial stability (van den Noord, 2005). Fiscal and macroprudential authorities may be required to collaborate, because Pigouvian taxes and levies may mitigate systemic externalities (IMF, 2010). Fiscal policy can influence macroprudential matters, as it can amplify or attenuate the procyclicality of the business cycle (Claessens, 2014).

Conflicts can also arise between macroprudential and structural policies. A very high LTV ratio, for example, is likely to increase the incidence of real estate booms (Claessens, 2014). Capital requirements which individual banks must fulfill may amplify the procyclicality of the financial system, even if they are optimally designed from a microprudential perspective (Repullo \& Suarez, 2013; Angelini, Enria, Neri, Panetta, \& Quagliariello, 2010). Similarly, deposit insurance and other forms of the public safety net can very well decrease the risk of runs on individual banks while simultaneously increasing systemic risk (Demirgüç-Kunt, Kane, \& Laeven, 2008; Demirgüç-Kunt \& Detragiache, 2002). Credit ratings may also aggravate the procyclicality of the business cycle (Amato \& Furfine, 2004). Furthermore, accounting rules which strive to promote market discipline and increase transparency can lead to more procyclical behavior because the "mark-to-market" accounting technique increases the likelihood of fire sales (Ellul, Jotikasthira, Lundblad, \& Wang, 2013; Leuz \& Laux, 2010). Moreover, a U-relationship between bank competition and financial stability can form due to changing risk-taking incentives (Allen \& Gale, 2004; Beck, 2008; Ratnovski, 2013). In addition, land use and construction policies can influence house price developments. In sum, macroprudential policies can be influenced by, and need to be coordinated with many other policies, such as monetary, microprudential, fiscal, and structural policies (Claessens, 2014). Indeed, the need for macroprudential policies partly arises from these exact policies. 


\section{Conclusion}

In this paper, we contrasted macroprudential policy with other economic policies and explained why other economic policies are unable to attain financial stability, which in turn justifies the need for a separate macroprudential policy, the ultimate goal whereof is precisely financial stability.

Before the 2007 financial crisis, all bank regulation was targeting individual banks despite the fact that central bankers, academics, and international institutions have advocated for some time that bank regulation should address the financial system as a whole, that is, the macroprudential perspective so as to mitigate the endogenous systemic risk (Gauthier, Lehar, \& Souissi, 2012). In order to prevent future financial crises, it is indispensable to combine both the microprudential and the macroprudential approach to financial stability. This is because the causes of the crises are often such that they cannot be prevented or mitigated by relying only on microprudential or only on macroprudential policy instruments. Moreover, other economic policies (monetary, fiscal, and structural policies) have different instruments and goals and as such do not lend themselves to the achievement of financial stability of the financial system as a whole. This provides a rationale for an additional economic policy - namely macroprudential policy - the sole focus of which is the safeguarding of financial stability of the financial system at large. Especially since the great financial crisis of 2007, there has been an increasing focus of policymakers and academics on the macroprudential approach to financial stability, as they have recognized that only by "marrying" both approaches do we stand a chance of preventing or at least reducing the likelihood of future crises (Knight, 2006; White, 2006; Borio, 2003). There are still many unknowns involved in using macroprudential policy tools. According to Mérö (2017), macroprudential targets are slightly ambiguous (decreasing systemic risk versus increasing the macroprudential shock-absorbing capacity of banks); we do not yet know or have evidence if the new macroprudential rules are suitably calibrated, if the usage of new instruments amplifies possibilities for regulatory arbitrage, what the interactions are between macroprudential and 
monetary policy, and if the usage of macroprudential tools can create certain risks - for instance those which arise from economic agents increasingly resorting to the use of unregulated shadow banking that is (currently) outside the purview of macroprudential legislation.

Even in 2014, more than seven years after the crisis, the meaning of the term "macroprudential regulation" was obscure (Barwell, 2013) and its effectiveness was debated (Galati \& Moessner, 2014). In the past few years, there has been a spike in the empirical and theoretical studies on the subject of macroprudential policy and macroprudential regulation. Since 2008, the usage of the term "macroprudential" in speeches by central bankers has surged, along with academic research on this topic (Galati \& Moessner, 2011). Nonetheless, there is still insufficient agreement on what constitutes a macroprudential policy framework, which stands in contrast with monetary policy framework where there is a clear consensus on the definition of an inflation-targeting regime (Lombardi \& Siklos, 2016). As such, delving into macroprudential policy framework could be an avenue for future research.

This paper was taking its final shape in 2020 and 2021, years marked by the coronavirus and the economic downturn resulting from it (Nakatani, 2020). Macroprudential policy measures and capital controls can be used during the coronavirus turmoil to help prevent economic crisis from transitioning into a financial crisis (Nakatani, 2020). There are concerns that emerging and developing economies could experience substantial capital outflows which may cause liquidity problems in domestic or foreign currencies in the banking and corporate sectors, in particular in the economies where currency mismatches and exchange rate depreciations are widespread (Nakatani, 2020). The coronavirus crisis could also have an adverse effect on the real estate sector and might lead to a decline in asset prices (Nakatani, 2020). Just as most central banks in the developed world eased monetary policy and engaged in extensive financial asset purchase programs during the COVID-19 pandemic, so too did macroprudential authorities ease macroprudential policy measures (e.g. they reduced capital and 
liquidity buffer requirements) to help financial institutions weather the first major economic downturn after the 2007 global financial crisis. While we do not examine the use and effectiveness of macroprudential policy measures in 2020 and 2021 (because the data which would be required for an empirical analysis were not yet available), this period is likely to be extensively studied in the future to evaluate if the easing of macroprudential requirements imposed on banks contributed to safeguarding the financial stability of the financial system against the backdrop of the COVID-19 pandemic.

\section{Literature}

Adrian, T., \& Shin, H. S. (2014). Procyclical leverage and value-at-risk. The Review of Financial Studies, 27(2), 373-403. doi: https://doi.org/10.1093/rfs/hht068

Agénor, P.-R., \& Pereira da Silva, L. A. (2014). Macroprudential regulation and the monetary transmission mechanism. Journal of Financial Stability, 13, 44-63. doi: https://doi.org/10.1016/j.jfs.2014.02.002

Akinci, O., \& Olmstead-Rumsey, J. (2018). How effective are macroprudential policies? An empirical investigation. Journal of Financial Intermediation, 33, 33 57. doi: https://doi.org/10.1016/j.jfi.2017.04.001

Allen, F., \& Gale, D. (2004). Competition and financial stability. Journal of Money, Credit, and Banking, 36(3), 453-480. Retrieved from:

https:/www.uio.no/studier/emner/sv/oekonomi/ECON4335/h14/pensumliste/ pensum/allengale3838946_129_240_48_177_13_08_2014_07_04.pdf

Altunbas, Y., Gambacorta, L., \& Marques-Ibanez, D. (2014). Does monetary policy affect bank risk? International Journal of Central Banking, 10(1), 95-135. Retrieved from: https://www.ijcb.org/journal/ijcb14q1a3.pdf

Amato, J. D., \& Furfine, C. H. (2004). Are credit ratings procyclical? Journal of Banking and Finance, 28(11), 2641-2677.

doi: https://doi.org/10.1016/j.jbankfin.2004.06.005 
Angelini, P., Enria, A., Neri, S., Panetta, F., \& Quagliariello, M. (2010). Procyclicality of capital regulation: Is it a problem? How to fix it? Bank of Italy Occasional Paper No. 74. doi: https://doi.org/10.2139/ssrn.1721563

Barwell, R. (2013). Macroprudential policy: Taming the wild gyrations of credit flows, debt stocks and asset prices. Palgrave Macmillan.

Beck, T. (2008). Bank competition and financial stability: Friends or foes? World Bank Policy Research Working Paper No. 4656.

doi: https://doi.org/10.1596/1813-9450-4656

Bengtsson, E. (in press). Macroprudential policy in the EU: A political economy perspective. Global Finance Journal. Retrieved from:

https://papers.ssrn.com/sol3/papers.cfm?abstract_id=3191023

Bini Smaghi, L. (2009, June). Going forward: Regulation and supervision after the financial turmoil. Speech held at the 4th International Conference of Financial Regulation and Supervision "After the Big Bang: Reshaping Central Banking, Regulation and Supervision", Bocconi University, Milan. Retrieved from: https://www.bis.org/review/r090623e.pdf

BIS. (1986). Recent innovations in international banking (Cross report). Basel: Bank for International Settlements. Retrieved from:

https://www.bis.org/publ/ecsc01.htm

Borio, C. (2003). Towards a macroprudential framework for financial supervision and regulation? BIS Working Paper No. 128.

doi: https://doi.org/10.2139/ssrn.841306

Borio, C. (2009, April 4). The macroprudential approach to regulation and supervision. VoxEU. Retrieved from:

https://voxeu.org/article/we-are-all-macroprudentialists-now

Borio, C. (2014). Macroprudential frameworks: (Too) great expectations? [Contribution to the 25th anniversary edition of Central Banking Journal]. Basel: Bank for International Settlements. Retrieved from: https://www.bis.org/speeches/sp140813.pdf

Borio, C., \& Drehmann, M. (2009). Assessing the risk banking crises - revisited. BIS Quarterly Review, March, 29-46. Retrieved from:

https://www.bis.org/publ/qtrpdf/r_qt0903e.pdf 
Borio, C., \& White, W. (2004). Whither monetary and financial stability? The implications of evolving policy regimes. BIS Working Paper No. 147. doi: https://doi.org/10.2139/ssrn.901387

Borio, C., \& Zhu, H. (2014). Capital regulation, risk-taking and monetary policy: A missing link in the transmission mechanism? Journal of Financial Stability, 8(4), 236-251. doi: https://doi.org/10.1016/j.jfs.2011.12.003

Bruno, V., Shim, I., \& Shin, H. S. (2017). Comparative assessment of macroprudential policies. Journal of Financial Stability, 28, 183-202.

doi: https://doi.org/10.1016/j.jfs.2016.04.001

Bryant, J. (1980). A model of reserves, bank runs, and deposit insurance. Journal of Banking and Finance, 4(4), 335-344.

doi: https://doi.org/10.1016/0378-4266(80)90012-6

Cecchetti, S. G., \& Kohler, M. (2012). When capital adequacy and interest rate policy are substitutes (and when they are not). BIS Working Paper No. 379. Retrieved from: https://www.bis.org/publ/work379.htm

Claessens, S. (2014). An overview of macroprudential policy tools. IMF Working Paper No. 14/214. doi: https://doi.org/10.5089/9781484358115.001

Claessens, S., Ghosh, S. R., \& Mihet, R. (2013). Macro-prudential policies to mitigate financial system vulnerabilities. Journal of International Money and Finance, 39(C), 153-185. doi: https://doi.org/10.1016/j.jimonfin.2013.06.023

Claessens, S., Kose, M. A., \& Terrones, M. E. (2011). How do business and financial cycles interact? IMF Working Paper No. 11/88.

doi: https://doi.org/10.5089/9781455233168.001

Crockett, A. D. (2000, September). Marrying the micro- and macroprudential dimensions of financial stability. BIS Speeches. Retrieved from: https://www.bis.org/speeches/sp000921.htm

Demirgüç-Kunt, A., \& Detragiache, E. (2002). Does deposit insurance increase banking system stability? An empirical investigation. Journal of Monetary Economics, 49(7), 1373-1406. doi: https://doi.org/10.1016/S0304-3932(02)00171-X

Demirgüç-Kunt, A., Kane, E., \& Laeven, L. (2008). Deposit insurance around the world: Issues of design and implementation. Cambridge, MA: MIT Press. 
Diamond, D. W., \& Dybvig, P. (1983). Bank runs, deposit insurance and liquidity. Journal of Political Economy, 91(3), 401-419.

doi: https://doi.org/10.1086/261155

ECB. (2013). Exploring the nexus between macro-prudential policies and monetary policy measures. Financial Stability Review, May, 99-111. Retrieved from: https://www.ecb.europa.eu/pub/pdf/fsr/art/ecb.fsrart201305_01.en.pdf

Elliott, D. J., Feldberg, G., \& Lehnert, A. (2013). The history of cyclical macroprudential policy in the United States. FEDS Working Paper No. 2013-29. doi: https://doi.org/10.2139/ssrn.2269090

Ellul, A., Jotikasthira, C., Lundblad, C. T., \& Wang, Y. (2013). Mark-to-market accounting and systemic risk: Evidence from the insurance industry. Fordham University Schools of Business Research Paper, September 2013.

doi: https://doi.org/10.2139/ssrn.2266247

Fahr, S., \& Fell, J. (2017). Macroprudential policy - closing the financial stability gap. Journal of Financial Regulation and Compliance, 25(4), 334-359.

doi: https://doi.org/10.1108/JFRC-03-2017-0037

Frait, J., \& Komárková, Z. (2011). Financial stability, systemic risk and macroprudential policy. In Czech National Bank, Financial stability report 2010/2011 (pp. 96-111). Retrieved from:

https://www.cnb.cz/export/sites/cnb/en/financial-stability/.galleries/fs_reports/ fsr_2010-2011/fsr_2010-2011_article_1.pdf

Galati, G., \& Moessner, R. (2011). Macroprudential policy - a literature review. BIS Working Paper No. 337. Retrieved from:

https://www.bis.org/publ/work337.pdf

Galati, G., \& Moessner, R. (2014). What do we know about the effects of macroprudential policy? DNB Working Paper No. 440.

doi: https://doi.org/10.2139/ssrn.2502003

Gambacorta, L., \& Murcia, A. (2020). The impact of macroprudential policies in Latin America: An empirical analysis using credit registry data. Journal of Financial Intermediation, 42(C). doi: https://doi.org/10.1016/j.jfi.2019.04.004 
Gauthier, C., Lehar, A., \& Souissi, M. (2012). Macroprudential capital requirements and systemic risk. Journal of Financial Intermediation, 21(4), 594618. doi: https://doi.org/10.1016/j.jfi.2012.01.005

Giese, J., Nelson, B., Tanaka, M., \& Tarashev, N. (2013). How could macroprudential policy affect financial system resilience and credit? Lessons from the literature. Bank of England Financial Stability Paper No. 21.

doi: https://doi.org/10.2139/ssrn.2266366

Greenwood-Nimmo, M., \& Tarassow, A. (2016). Monetary shocks, macroprudential shocks and financial stability. Economic Modelling, 56, 11-24. doi: https://doi.org/10.1016/j.econmod.2016.03.003

Hanson, S. G., Kashyap, A. K., \& Stein, J. C. (2011). A macroprudential approach to financial regulation. Journal of Economic Perspectives, 25(1), 3-28. doi: https://doi.org/10.1257/jep.25.1.3

IMF. (2010). A fair and substantial contribution by the financial sector: Final report for the G-20. Retrieved from: http://www.imf.org/external/np/g20/pdf/062710b.pdf

IMF. (2011). Macroprudential policy: An organizing framework. Retrieved from: https://www.imf.org/external/np/pp/eng/2011/031411.pdf

IMF. (2013a). The interaction of monetary and macroprudential policies. Background paper. Retrieved from: https:/www.imf.org/external/np/pp/eng/2013/012713.pdf

IMF. (2013b). Key aspects of macroprudential policy. Retrieved from: https://www.imf.org/external/np/pp/eng/2013/061013b.pdf

Keen, M., \& de Mooij, R. (2012). Debt, taxes, and banks. IMF Working Paper No. 12/48. doi: https://doi.org/10.5089/9781463937096.001

Kiley, M. T., \& Sim, J. (2017). Optimal monetary and macroprudential policies: Gains and pitfalls in a model of financial intermediation. Journal of Macroeconomics, 54(B), 232-259. doi: https://doi.org/10.1016/j.jmacro.2017.05.008

Kindleberger, C. P. (1978). Manias, panics and crashes: A history of financial crises. Palgrave Macmillan. 
Klingelhöfer, J., \& Sun, R. (2019). Macroprudential policy, central banks and financial stability: Evidence from China. Journal of International Money and Finance, 93, 19-41. doi: https://doi.org/10.1016/j.jimonfin.2018.12.015

Knight, M. D. (2006, October). Marrying the micro- and macroprudential dimensions of financial stability: Six years on. BIS Speeches. Retrieved from: https://www.bis.org/speeches/sp061005.htm

Koh, E. T., \& Owen, W. L. (2000). Descriptive research and qualitative research. In E. T. Koh \& W. L. Owen (Eds.), Introduction to nutrition and health research (pp. 219-248). Boston, MA: Springer.

doi: https://doi.org/10.1007/978-1-4615-1401-5_12

Lamfalussy, A. (2004, October). Central banks and financial stability. 2nd Pierre Werner Lecture delivered in Luxembourg. Luxembourg: Banque Centrale de Luxembourg. Retrieved from:

https://www.bcl.lu/en/Media-and-News/Speeches/archives/2004/20041026/ Discours_Lamfalussy.pdf

Leuz, C., \& Laux, C. (2010). Did fair-value accounting contribute to the financial crisis? Journal of Economic Perspectives, 24(1), 93-118.

doi: https://doi.org/10.1257/jep.24.1.93

Lombardi, D., \& Siklos, P. L. (2016). Benchmarking macroprudential policies: An initial assessment. Journal of Financial Stability, 27, 35-49.

doi: https://doi.org/10.1016/j.jfs.2016.08.007

Maes, I. (2010). Alexandre Lamfalussy and the origins of the BIS macroprudential approach to financial stability. PSL Quarterly Review, 63(254), 265292. Retrieved from: https://ideas.repec.org/a/psl/pslqrr/201034.html

Malz, A. M. (2019). Macroprudential policy, leverage, and bailouts. Cato Journal, 39(3), 499-528. doi: https://doi.org/10.36009/CJ.39.3.2

Mérö, K. (2017). The emergence of macroprudential bank regulation: A review. Acta Oeconomica, 67(3), 289-309. doi: https://doi.org/10.1556/032.2017.67.3.1

Minsky, H. P. (1977). The financial instability hypothesis: An interpretation of Keynes and an alternative to "standard" theory. Nebraska Journal of Economics and Business, 16(1), 5-16. Retrieved from: https://www.jstor.org/stable/40472569 
Morris, S., \& Shin, H. S. (2008). Coordinating expectations in monetary policy. In J.-P. Touffut (Ed.), Central banks as economic institutions (pp. 88-104). Northampton, MA: Edward Elgar Publishing.

Mundell, R. A. (1962). The appropriate use of monetary and fiscal policy for internal and external stability. IMF Economic Review, 9(1), 70-79.

Nakatani, R. (2020). Macroprudential policy and the probability of a banking crisis. Journal of Policy Modeling, 42(6), 1169-1186.

doi: https://doi.org/10.1016/j.jpolmod.2020.05.007

Osinski, J., Seal, K., \& Hoogduin, L. (2013). Macroprudential and microprudential policies: Toward cohabitation. IMF Staff Discussion Note No. 13/5.

doi: https://doi.org/10.5089/9781484369999.006

Ratnovski, L. (2013). Competition policy for modern banks. IMF Working Paper No. 13/126. doi: https://doi.org/10.5089/9781484354728.001

Repullo, R., \& Suarez, J. (2013). The procyclical effects of bank capital regulation. Review of Financial Studies, 26(2), 452-490.

doi: https://doi.org/10.1093/rfs/hhs118

Rubio, M., \& Carrasco-Gallego, J. A. (2014). Macroprudential and monetary policies: Implications for financial stability and welfare. Journal of Banking \& Finance, 49, 326-336. doi: https://doi.org/10.1016/j.jbankfin.2014.02.012

Rubio, M., \& Comunale, M. (2018). Macroeconomic and financial stability in a monetary union: The case of Lithuania. Economic Systems, 42(1), 75-90. doi: https://doi.org/10.1016/j.ecosys.2017.04.002

Schoenmaker, D., Gross, D., Langfield, S., \& Pagano, M. (2014). Allocating macroprudential powers. ESRB Report of the Advisory Scientific Committee No. 5. Retrieved from: https://www.esrb.europa.eu/pub/pdf/asc/Reports_ASC_5_1411.pdf

Schüler, Y. S., Hiebert, P. P., \& Peltonen, T. A. (2015). Characterising the financial cycle: A multivariate and time-varying approach. ECB Working Paper No. 1846. Retrieved from: https://www.ecb.europa.eu/pub/pdf/scpwps/ecbwp1846.en.pdf

Svensson, L. E. O. (2018). Monetary policy and macroprudential policy: Different and separate? Canadian Journal of Economics, 51(3), 802-827.

doi: https://doi.org/10.1111/caje.12345 
Tayler, W. J., \& Zilberman, R. (2016). Macroprudential regulation, credit spreads and the role of monetary policy. Journal of Financial Stability, 26, 144-158. doi: https://doi.org/10.1016/j.jfs.2016.08.001

Tinbergen, J. (1952). On the theory of economic policy. Amsterdam: North Holland Publishing Company.

Tomuleasa, I.-I. (2015). Macroprudential policy and systemic risk: An overview. Procedia Economics and Finance, 20, 645-653. doi: https://doi.org/10.1016/S2212-5671(15)00119-7

Tröger, T. H. (2015). Regulatory influence on market conditions in the banking union: The cases of macro-prudential instruments and the bail-in tool. European Business Organization Law Review, 16, 575- 593.

doi: https://doi.org/10.1007/s40804-015-0020-0

Ueda, K., \& Valencia, F. (2012). Central bank independence and macroprudential regulation. IMF Working Paper No. 12/101.

doi: https://doi.org/10.5089/9781475502916.001

van den End, J. W. (2016). Quantitative easing tilts the balance between monetary and macroprudential policy. Applied Economics Letters, 23(10), 743-746. doi: https://doi.org/10.1080/13504851.2015.1105913

van den Noord, P. (2005). Tax incentives and house price volatility in the euro area: Theory and evidence. Economie Internationale, 101, 29-45.

doi: https://doi.org/10.3917/ecoi.101.0029

White, W. R. (2006). Procyclicality in the financial system: Do we need a new macrofinancial stabilisation framework? BIS Working Paper No. 193.

doi: https://doi.org/10.2139/ssrn.891765

Woodford, M. (2005). Central bank communication and policy effectiveness. NBER Working Paper No. 11898. doi: https://doi.org/10.3386/w11898 